\title{
Motoros pótló mútétek a kézsebészetben IV. Pótló mưtétek a nervus ulnaris sérülése után
}

\author{
DR. RENNER ANTAL, DR. RUPNIK JÁNOS JR., DR. EGRI LÁSZLÓ, \\ DR. SZENTIRMAI ANNAMÁRIA
}

\section{ÖSSZEFOGLALÁS}

A nervus ulnaris sérülése után visszamaradó funkciókárosodás helyreállítására végzett pótló mútétek eredményeiről számolunk be, 20 éves beteganyagunk utánvizsgálata alapján. 17 betegen ( 8 proximalis, 9 distalis) 32 mútétet végeztünk. Szeptikus szövődményünk nem volt. A kilencféle mútét karomtartás megszüntetésére: Fowler, Brand, Bunnell, Zancolli; karomtartás csökkentésére: Zancolli; mutatóujj stabilizálásra kulcsfogáshoz: Bunnell, Littler; hüvelykujj adductor pótlásra: Solonen-Bakalim, Boyes eredményeinek egymással való összehasonlítására a kis esetszám nem alkalmas ugyan, de az eredmények egyértelműen igazolták, hogy a legsúlyosabb kéz funkciózavart is eredményesen javíthatjuk a motoros pótló mútétekkel, a munkavégzéshez szükséges fő funkciók helyreállíthatók, a beteg leszázalékolása elkerülhető. Az értékelést a DASH Score, a kéz és a kulcsfogás szorítóerejének mérése, továbbá a hüvelyk adductio, a mutatóujj abductio mérése, és az ellenoldali kézhez viszonyított százaléka alapján végeztük.

\section{Kulcsszavak: $\quad$ Kézsérülés; Idegsérülés; Kontraktúra; Perifériális idegek; Rekonstruktiv sebészet; Ulnaris ideg;}

A. Renner, J. Rupnik, L. Egri, A. Szentirmai: Reconstructive operations of motor organs in hand surgery. IV. Surgical replacements for the lesion of the ulnar nerve

Based on the follow-up evaluation of patients treated during a 20 years period, we report about the results of surgical replacements performed for remaining functional impairment after ulnar nerve lesion. We performed 32 surgeries on 17 patients ( 8 proximal and 9 distal interventions). There were no septic complications. There are nine types of surgery for the correction of the claw position of the fingers: Fowler, Brand, Bunnell, Zancolli; for the reduction of the claw position of the fingers: Zancolli; for the stabilization of the index finger to restore the pinch grip: Bunnell, Littler; for the replacement of the adductor function of the thumb: Solonen-Bakalim, Boyes-procedure. This little number of cases makes no comparisons possible, but their results confirmed that even the most severe functional impairment of the hand may be successfully corrected by restoration of the motor functions and disability can be avoided. For the evaluation we applied the DASH score, measuring the strength of the pinch grip, assessment of the abduction of the index finger, compared to the respective values measured on the opposite hand; the results were represented in percent.

Keywords: $\quad$ Hand injuries - Surgery; Nerve regeneration;

Peripheral nerves - Injuries/Surgery;

Reconstructive surgical techniques;

Ulnar nerve - Injuries/Surgery; 


\section{BEVEZETÉS}

A felső végtagi funkciók idegsérülés következtében kialakult károsodásának helyreállítását nyújtó motoros pótló mútétekről szóló sorozatunk negyedik közleményét tartja kezében az olvasó, amely a nervus ulnaris károsodás utáni helyreállítás lehetőségeivel foglalkozik.

A kiesett funkciók helyreállítására a szakirodalomban már a XIX. század vége óta számtalan módszert írtak le különböző szerzők, több módszert ma már nem tartanak megfelelőnek, több módszer pedig különböző módosításokkal ma is jó eredménnyel alkalmazható $(1-3,5,12-14,25,26,29,30,32)$.

E közleménnyel célunk az, hogy saját, 20 évnyi beteganyagunkon bemutassuk azokat a mútéti lehetőségeket, amelyeket 1990-2009 között intézetünkben sikeresen alkalmaztunk.

Eltérően a nervus medianus és a nervus radialis sérülések utáni pótló mútétektől, a nervus ulnaris esetében a kéz mozgásait irányító és végrehajtó anatómiai rendszerek többszörös károsodásával találkozunk, s ennek arányában a kéz összfunkciója is jóval súlyosabban károsodott (1. ábra). Emiatt a késői motoros rekonstrukció is sokkal nehezebb $(4,6,7,8,17,31)$. A szenzibilitás kiesése a nervus ulnaris sérülésében kevésbé zavaró, mint a nervus medianus sérülésében, a legtöbb beteg megtanul együtt élni ezzel (11). A korszerű kézsebészet előtti időkben, a kisujjon kialakuló trophicus zavar és a hidegérzékenység miatt egyes betegek kérésére, a kisujj amputációjára is sor kerülhetett.

$\mathrm{Az}$ egyes izmok hivatalos rövidítéseit sorozatunk II. közleményének I. táblázatában közöltük (21).

Nervus ulnaris „mély”, vagy „distalis sérülésében bénult izmok:

- adductor pollicis

- flexor pollicis brevis mély feje

- interosseusok és a IV. V. lumbricalis

- intrinsic kisizmok

- adductor digiti minimi

- flexor digiti minimi brevis

- opponens digiti minimi

\section{Elvesztett funkciók és tünetek:}

- érzéskiesés a nervus ulnaris szenzoros területén a kézen
- hosszú ujjak MP ízületének hajlítása

- hosszú ujjak PIP és DIP ízületek nyújtása

- megbomlik az ujjak hajlításának összerendezettsége

- nyújtott helyzetben elvész a hosszú ujjak radialés ulnarductiója

- a kéz harántboltozata ellapul

- kialakul a jellegzetes "karomállás": hyperextenió a hosszú ujjak MP ízületében, flexio a PIP és DIP ízületekben, ami legkifejezettebb a gyűrús- és a kisujjon

- „rejtett karomállás” látható a mutató- és a középső ujjakon, mert ezen a két ujjon a nervus medianus által beidegzett lumbricalis izom ép, ezért a PIP és DIP ízület nyújtása megtartott, de erőtlen

- elvész a hüvelykujj adductiója

- kiesik a mutatóujj radialductiója

- kiesik a mutatóujj abductiója.

- erőtlen lesz a csúcs- és kulcsfogás a hüvelykujjal (Froment jel)

Nervus ulnaris „magas”, vagy „proximalis” sérülésében bénult izmok:

- minden, ami a „mély” sérülésnél, továbbá

- m. flexor carpi ulnaris (FCU)

- m. flexor digitorum profundus a gyúrús- és kisujjon (FDP IV-V)

- bénult lehet a $\mathrm{m}$. flexor digitorum profundus III is (FDP III)

Megjegyzés: A nervus ulnaris és medianus közötti összeköttetések, főleg a Martin-Gruber anastomosis miatt, számos eltérés lehet az intrinsic izmok és a profundus izmok beidegzésében, ezért rendkívül gondos vizsgálat szükséges, EMG, ENG is indokolt (28)!

\section{Elvesztett funkciók és tünetek:}

- érzéskiesés a n. ulnaris szenzoros területén a kézháton és az alkaron is

- hosszúujjak „karomállása” (2. ábra)

- elvész a hüvelykujj stabilitása és adductiója

- kiesik a mutatóujj abductiója

- elvész a hüvelykujj és a mutatóujj közötti fogásképesség

- kiesik a gyúrüs- és kisujj flexiója

- a kisujj abducált helyzetben áll (Wartenberg jel)

Megjegyzés: Az FCU és az FDP IV-V bénultsága miatt a tipikus „karomállás” kevésbé kifejezettnek látszik, mint a distalis károsodásban. 


\section{Helyreállítandó funkciók distalis károso- dásban: \\ - a karomállás megszüntetése, az ujjhajlítás in- tegrációja \\ - a csúcsfogás erősítése \\ - a hüvelykujj adductiójának pótlása \\ - a mutató- és a középsőujj radial- ductiójának pótlása (egyben a „rejtett karomállás" megszüntetése is)}

\section{Helyreállítandó funkciók proximalis káro- sodásban:}

- Az intrinsic izmok területén ugyanazokat a múködéseket helyreállítani, mint az ideg "mély" sérülése esetén.

- Az ulnaris oldali mélyhajlítók múködése. (Ha a középsőujj mélyhajlító ina ép, ehhez lehet kapcsolni a gyűrűs- és a kisujj bénult mélyhajlító inait).

Fontos! Azon ujj felületes hajlítóinát nem használhatjuk fel íntranszpozícióra, amelyen a mély hajlítóín bénult!

\section{A pótló mútétek feltétele:}

- Az ujjak, ujjízületek szabad aktív-passzív mozgása! Ennek hiányában inkább az arthrodesis javasolt.

- Kísérő sérülések felmérése, van-e alkalmas motor a beteg kezén, felső végtagján?

- Alapos, mindenre kiterjedő anamnézis felvétel és betegvizsgálat:

- mi a foglalkozása, milyen egyéb aktivitást végez kezével

- munkájában milyen kézfunkció a legfontosabb

- melyik elvesztett funkció jelenti számára a legnagyobb problémát

- domináns vagy nem domináns keze sérült

Megjegyzés: Az összes elvesztett funkciót nem tudjuk pótolni, soha ne keltsünk a betegben túlzott várakozást!

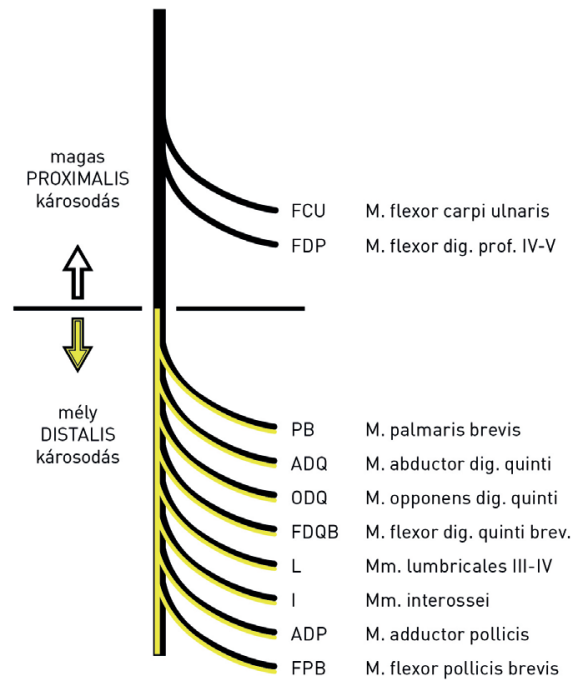

1. ábra Nervus ulnaris proximalis és distalis sérülésében bénult izmok

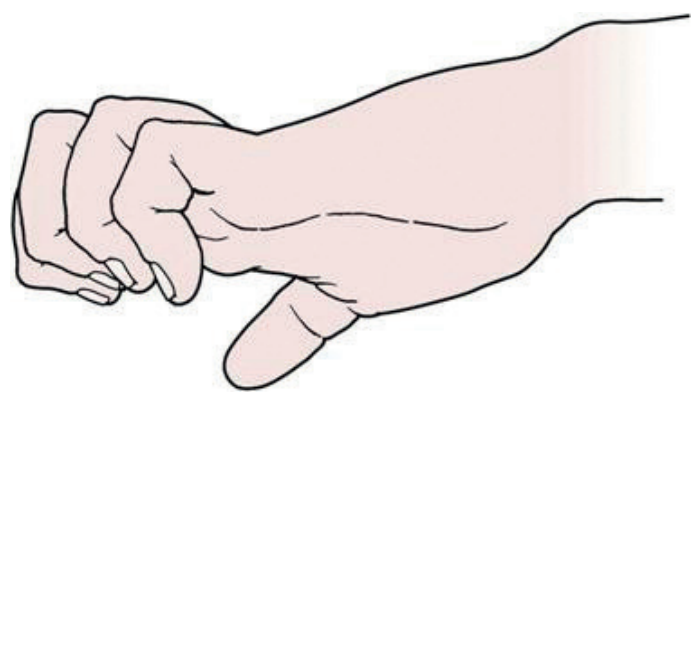

2. ábra Típusos tünet a hosszúujjak karomállása nervus ulnaris sérülésben 


\section{ANYAG ÉS MÓDSZER}

$\mathrm{Az}$ egykori Országos Traumatológiai Intézet, majd Országos Baleseti és Sürgősségi Intézet - jelenleg: Péterfy Kórház-Rendelőintézet Országos Traumatológiai Intézet Kéz- és Mikrosebészeti Osztályán - 1990. január 1. és 2009. december 31. között, 215 betegnél végeztünk motoros pótló mútétet a felső végtagon, perifériás idegsérülés következtében kialakult funkciókárosodás miatt. Ezen belül a nervus ulnaris sérülés utáni károsodás miatt 17 betegnél ( 8 proximalis, 9 distalis) került sor 32 funkciójavító motoros pótló mútétre (I. táblázat). Hat beteg sérülésének primer ellátása más intézményben történt. A pótló mútétre átlagosan 9,2 hónap után került sor (5-18 hónap).

A betegeink kezeléséhez alkalmazott mútéti eljárásokat - a vizsgált időszak első felében, kézsebészeti képzettségünk érlelődő szakaszában - a szakirodalom akkor ismertetett, ajánlott módszerei közül választottuk (2, 3, 9, 12, 13, 15). Ezek, az évek múlásával, a külföldi tanulmányútjainkon szerzett új ismeretek birtokában, és saját mútéti tapasztalataink alapján a második évtizedben gazdagodtak, és a betegek igényeihez egyre megfelelőbbé váltak $(4-6,16,18,27)$. A két betegcsoport adatait, a végzett mútéteket a II. és III. táblázatokban foglaltuk össze.

\begin{tabular}{|c|c|c|}
\hline Végzett mútét típusa & Íntranszpozíció & Mútét száma \\
\hline Karomtartás megszüntetése feszítőoldali mútéttel (Fowler 1949) & $\begin{array}{l}\text { EIP ad tractus lateralis } \\
\text { EDM ad tractus lateralis }\end{array}$ & 1 \\
\hline Karomtartás megszüntetése feszítőoldali mútéttel (Brand 1961) & $\mathrm{ECRBr}+$ graftok ad tractus lateralis & 1 \\
\hline $\begin{array}{l}\text { Karomtartás megszüntetése hajlítóoldali mútéttel } \\
\text { (Bunnell 1942; Nussbaum - Stiles 1916) }\end{array}$ & FDS III ad tractus lateralis & 3 \\
\hline $\begin{array}{l}\text { Karomtartás megszüntetése lasszó-plasztikával } \\
\text { (Zancolli 1974) }\end{array}$ & Dinamikus tenodesis FDS ínnal & 5 \\
\hline $\begin{array}{l}\text { Karomtartás csökkentése capsulodesissel } \\
\text { (Zancolli 1957) }\end{array}$ & Capsulodesis & 8 \\
\hline $\begin{array}{l}\text { Mutatóujj stabilizálása kulcsfogáshoz } \\
\text { (Bunnell 1940) }\end{array}$ & EIP I.dorsalis interosseusra & 7 \\
\hline $\begin{array}{l}\text { Mutatóujj stabilizálása kulcsfogáshoz } \\
\text { (Littler 1949) }\end{array}$ & $\begin{array}{l}\text { EIP I. dorsalis interosseusra }+1 . \\
\text { MP desis }\end{array}$ & 1 \\
\hline $\begin{array}{l}\text { Hüvelykujj adductor pótlása } \\
\text { (Solonen-Bakalim 1976) }\end{array}$ & $E C R L+$ graft $A D P$ & 2 \\
\hline $\begin{array}{l}\text { Hüvelykujj adductor pótlása } \\
\text { (Boyes 1964) }\end{array}$ & $\mathrm{BR}+$ graft $\mathrm{ADP}$ & 4 \\
\hline
\end{tabular}




\section{II. táblázat Pótló mütétek nervus ulnaris „magas” sérülése után}

\begin{tabular}{|c|c|c|c|c|c|c|c|c|c|}
\hline & név & nem & kor & $\begin{array}{c}\text { foglalko- } \\
\text { zás }\end{array}$ & pótló mútét előzményei & $\begin{array}{c}\text { eltelt } \\
\text { idő }\end{array}$ & Pótló mútét & $\begin{array}{l}\text { DASH } \\
\text { Score }\end{array}$ & $\begin{array}{l}\text { Ered- } \\
\text { mény }\end{array}$ \\
\hline 1. & H.A.V. & ffi & 32 & $\begin{array}{l}\text { kereske- } \\
\text { dő }\end{array}$ & $\begin{array}{l}\text { Autóbaleset } \\
\text { Bal o. nyílt felkartörés + } \\
\text { idegsérülés } \\
\text { Osteosynthesis } \\
\text { Idegvarrat nem történt } \\
\text { NEM DOMINÁNS KÉZ }\end{array}$ & $\begin{array}{l}8 \\
\text { hó }\end{array}$ & $\begin{array}{c}\text { Mutatóujj stabilizálása } \\
\text { kulcsfogáshoz: (Bunnell) } \\
\text { EIP } \rightarrow>\text { I. dorsalis interosseusra } \\
\text { Hüvelykujj adductor pótlása } \\
\text { (Boyes) } \\
\text { BR + graft -> ADP } \\
\text { Karomtartás megszüntetése: } \\
\text { (Brand) } \\
\text { ECRBr + graftok }->\text { ad tractus } \\
\text { lateralis }\end{array}$ & 33,5 & jó \\
\hline 2. & B.F. & ffi & 36 & kőműves & $\begin{array}{c}\text { Állványról leesett } \\
\text { Jobb o. proximalis felkartörés } \\
\text { + idegsérülés } \\
\text { Osteosynthesis; Primer } \\
\text { idegvarrat } \\
\text { NEM DOMINÁNS KÉZ }\end{array}$ & $\begin{array}{l}14 \\
\text { hó }\end{array}$ & $\begin{array}{c}\text { Karomtartás megszüntetése: } \\
\text { (Zancolli) } \\
\text { Lasszó-plasztika }\end{array}$ & 32,5 & jó \\
\hline 3. & M.K. & nő & 44 & $\begin{array}{l}\text { takarí- } \\
\text { tónő }\end{array}$ & $\begin{array}{l}\text { Ablaküvegbe esett, jobb } \\
\text { csuklója sérült } \\
\text { Lágyrész- és idegsérülés } \\
\text { DOMINÁNS KÉZ }\end{array}$ & $\begin{array}{c}6 \\
\text { hó }\end{array}$ & $\begin{array}{c}\text { Karomtartás megszüntetése: } \\
\text { (Zancolli) } \\
\text { Lasszó-plasztika }\end{array}$ & 85 & gyenge \\
\hline 4. & N.G. & ffi & 28 & eladó & $\begin{array}{c}\text { Autóbaleset } \\
\text { Jobb o. nyílt felkartörés + } \\
\text { idegsérülés } \\
\text { OS; Primer idegvarrat } \\
\text { DOMINÁNS KÉZ }\end{array}$ & $\begin{array}{l}8 \\
\text { hó }\end{array}$ & $\begin{array}{c}\text { Karomtartás csökkentése: } \\
\text { (Zancolli) } \\
\text { Capsulodesis }\end{array}$ & 53,25 & $\begin{array}{c}\text { megfe- } \\
\text { leló }\end{array}$ \\
\hline 5. & L.I. & ffi & 16 & tanuló & $\begin{array}{c}\text { Jobb o. proximalis } \\
\text { felkartörés; } \\
\text { Primeren nem diagnosztizált } \\
\text { idegsérülés } \\
\text { DOMINÁNS KÉZ }\end{array}$ & $\begin{array}{l}18 \\
\text { hó }\end{array}$ & $\begin{array}{l}\text { Mutatóujj stabilizálása } \\
\text { kulcsfogáshoz: (Bunnell) } \\
\text { EIP -> I. dorsalis interosseusra } \\
\text { Hüvelykujj adductor pótlása: } \\
\text { (Solonen-Bakalim) } \\
\text { ECRL + graft -> ADP } \\
\text { Karomtartás megszüntetése: } \\
\text { (Zancolli) } \\
\text { Lasszó-plasztika }\end{array}$ & 12,75 & kiváló \\
\hline 6. & N.M.G. & ffi & 34 & mérnök & $\begin{array}{c}\text { Otthonában létráról } \\
\text { ablaküvegbe esett } \\
\text { Jobb o. nyílt felkartörés + } \\
\text { idegsérülés } \\
\text { Más kórházban OS; Primer } \\
\text { idegvarrat } \\
\text { DOMINÁNS KÉZ }\end{array}$ & $\begin{array}{l}11 \\
\text { hó }\end{array}$ & $\begin{array}{c}\text { Karomtartás csökkentése: } \\
\text { (Zancolli) } \\
\text { Capsulodesis }\end{array}$ & 10 & kiváló \\
\hline 7. & K.A. & ffi & 26 & $\begin{array}{l}\text { segéd- } \\
\text { munkás }\end{array}$ & $\begin{array}{l}\text { Állványról leesett } \\
\text { Bal o. nyílt felkartörés + } \\
\text { idegsérülés } \\
\text { Osteosynthesis } \\
\text { Idegvarrat halasztottan } \\
\text { NEM DOMINÁNS KÉZ }\end{array}$ & $\begin{array}{l}7 \\
\text { hó }\end{array}$ & $\begin{array}{l}\text { Mutatóujj stabilizálása } \\
\text { kulcsfogáshoz: (Bunnell) } \\
\text { EIP -> I. dorsalis interosseusra } \\
\text { Hüvelykujj adductor pótlása } \\
\text { (Boyes) } \\
\text { BR + graft -> ADP } \\
\text { Karomtartás csökkentése: } \\
\text { (Zancolli) } \\
\text { Capsulodesis }\end{array}$ & 17,5 & kiváló \\
\hline 8. & K.J. & nő & 19 & $\begin{array}{l}\text { takarí- } \\
\text { tónő }\end{array}$ & $\begin{array}{l}\text { Késsel megszúrták jobb } \\
\text { felkarját } \\
\text { Lágyrész sérülés ellátása } \\
\text { Primeren nem észlelt } \\
\text { idegsérülés } \\
\text { Késői idegvarrat } \\
\text { DOMINÁNS KÉZ }\end{array}$ & $\begin{array}{l}5 \\
\text { hó }\end{array}$ & $\begin{array}{c}\text { Mutatóujj stabilizálása } \\
\text { kulcsfogáshoz: (Bunnell) } \\
\text { EIP -> I. dorsalis interosseusra } \\
\text { Hüvelykujj adductor pótlása: } \\
\text { (Solonen-Bakalim) } \\
\text { ECRL + graft -> ADP } \\
\text { Karomtartás csökkentése: } \\
\text { (Zancolli) } \\
\text { Capsulodesis }\end{array}$ & 36 & jó \\
\hline
\end{tabular}




\begin{tabular}{|c|c|c|c|c|c|c|c|c|c|}
\hline & név & nem & kor & foglalkozás & pótló mútét előzményei & $\begin{array}{l}\text { eltelt } \\
\text { idő }\end{array}$ & Pótló mútét & $\begin{array}{l}\text { DASH } \\
\text { Score }\end{array}$ & $\begin{array}{l}\text { Ered- } \\
\text { mény }\end{array}$ \\
\hline 1. & H.J. & ffi & 31 & $\begin{array}{l}\text { fizikai } \\
\text { munkás }\end{array}$ & $\begin{array}{l}\text { Autóbaleset, ablakon kiesett, az } \\
\text { üveg vágta el jobb csuklóját } \\
\text { Lágyrész ellátás } \\
\text { Halasztott idegvarrat } \\
\text { DOMINÁNS KÉZ }\end{array}$ & 8 hó & $\begin{array}{c}\text { Mutatóujj stabilizálás kulcsfogáshoz: } \\
\text { (Littler) } \\
\begin{array}{c}\text { EIP } \rightarrow>\text { I. dorsalis interosseusra + I. MP } \\
\text { desis a } \\
\text { hüvelykujjon }\end{array} \\
\text { Karomtartás megszüntetése: (Bunnell) } \\
\text { FDS III -> ad tractus lateralis }\end{array}$ & 32.25 & jó \\
\hline 2. & P.J. & ffi & 22 & $\begin{array}{l}\text { egyetemi } \\
\text { hallgató }\end{array}$ & $\begin{array}{c}\text { Szúrt sérülés jobb alkaron } \\
\text { Vidéki kórházban primer idegvarrat } \\
\text { DOMINÁNS KÉZ }\end{array}$ & 7 hó & $\begin{array}{l}\text { Karomtartás csökkentése: (Zancolli) } \\
\text { Capsulodesis }\end{array}$ & 10 & kiváló \\
\hline 3. & $\begin{array}{l}\text { H.J- } \\
\text { né. }\end{array}$ & nő & 36 & $\begin{array}{l}\text { háztartás- } \\
\text { beli }\end{array}$ & $\begin{array}{l}\text { Ablaktisztítás közben betört } \\
\text { ablaküveg vágta el jobb csuklóját } \\
\text { Lágyrész ellátás } \\
\text { Halasztott idegvarrat } \\
\text { DOMINÁNS KÉZ }\end{array}$ & 11 hó & $\begin{array}{l}\text { Mutatóujj stabilizálása kulcsfogáshoz: } \\
\text { (Bunnell) } \\
\text { EIP -> I. dorsalis interosseusra } \\
\text { Hüvelykujj adductor pótlása (Boyes) } \\
\text { BR + graft -> ADP } \\
\text { Karomtartás megszüntetése: (Bunnell) } \\
\text { FDS III: -> ad tractus lateralis }\end{array}$ & 28,5 & jó \\
\hline 4. & K.I. & nő & 27 & tanár & $\begin{array}{l}\text { Mosogatás közben törött pohár } \\
\text { vágta el jobb csuklóját } \\
\text { Lágyrész ellátás } \\
\text { Halasztott idegvarrat } \\
\text { DOMINÁNS KÉZ }\end{array}$ & 11 hó & $\begin{array}{l}\text { Mutatóujj stabilizálása kulcsfogáshoz: } \\
\text { (Bunnell) } \\
\text { EIP } \rightarrow>\text { I. dorsalis interosseusra } \\
\text { Karomtartás megszüntetése: (Fowler) } \\
\text { FDS III }->\text { ad tractus lateralis } \\
\text { EDM } \rightarrow>\text { ad tractus lateralis }\end{array}$ & 27,75 & jó \\
\hline 5. & Sz.J. & ffi & 24 & asztalos & $\begin{array}{l}\text { Véső sértette bal csuklóját } \\
\text { Primer idegvarrat } \\
\text { NEM DOMINÁNS KÉZ }\end{array}$ & 6 hó & $\begin{array}{l}\text { Karomtartás csökkentése: (Zancolli) } \\
\text { Capsulodesis }\end{array}$ & 10 & kiváló \\
\hline 6. & S.M. & nő & 37 & titkárnő & $\begin{array}{l}\text { Olló megszúrta bal csuklóját. } \\
\text { N. ulnaris motoros ága sérült } \\
\text { Primer idegvarrat } \\
\text { DOMINÁNS KÉZ }\end{array}$ & 14 hó & $\begin{array}{c}\text { Karomtartás megszüntetése: (Bunnell) } \\
\text { EIP } \rightarrow \text { ad tractus lateralis }\end{array}$ & 16,75 & kiváló \\
\hline 7. & K.D. & ffi & 16 & tanuló & $\begin{array}{l}\text { Fafaragás közben késsel elvágta } \\
\text { bal csuklóját } \\
\text { Lágyrész ellátás halasztott } \\
\text { idegvarrat } \\
\text { NEM DOMINÁNS KÉZ }\end{array}$ & 7 hó & $\begin{array}{l}\text { Karomtartás csökkentése: (Zancolli) } \\
\text { Capsulodesis }\end{array}$ & 6,25 & kiváló \\
\hline 8. & K.A. & ffi & 20 & $\begin{array}{l}\text { egyetemi } \\
\text { hallgató }\end{array}$ & $\begin{array}{c}\text { Korcsolya átment a jobb csuklóján } \\
\text { Roncsolt lágyrészek ellátása } \\
\text { Halasztott idegvarrat } \\
\text { DOMINÁNS KÉZ }\end{array}$ & 12 hó & $\begin{array}{l}\text { Karomtartás megszüntetése: (Zancolli) } \\
\text { Lasszó-plasztika }\end{array}$ & 9,25 & kiváló \\
\hline 9. & K.M. & ffi & 42 & $\begin{array}{l}\text { segédmun- } \\
\text { kás }\end{array}$ & $\begin{array}{c}\text { Épületbontás közben bal csukló } \\
\text { roncsolt sérülése } \\
\text { Lágyrész ellátás } \\
\text { Halasztott idegvarrat } \\
\text { NEM DOMINÁNS KÉZ }\end{array}$ & 10 hó & $\begin{array}{l}\text { Mutatóujj stabilizálása kulcsfogáshoz: } \\
\text { (Bunnell) } \\
\text { EIP -> I. dorsalis interosseusra } \\
\text { Hüvelykujj adductor pótlása (Boyes) } \\
\text { BR + graft -> ADP } \\
\text { Karomtartás megszüntetése: (Zancolli) } \\
\text { Lasszó-plasztika }\end{array}$ & 48 & jó \\
\hline
\end{tabular}

Helyreállító mütéteink a nervus ulnaris distalis károsodása után

\section{Karomtartás megszüntetése feszítő ol- dali mútéttel}

\section{A) FOWLER módszere szerint}

Cél: mindkét interphalangealis ízület aktív nyújtása

Indikáció: rövid extensorok pótlása

Mütét képlete:

\section{EIP $\rightarrow$ ad tractus lateralis II-III $\mathrm{EDM} \rightarrow$ ad tractus lateralis IV-V}

Megjegyzés: Az eredeti leírás szerint a négy hosszúujj karomállásának a korrekciójára a mutatóujj és a kisujj saját feszítő inát alkalmazták. Később - napjainkban is - csak az EIP-t használják a gyűrűs- és kisujj korrekciójára.

Mútéti technika:

- Haránt ívelt bőrmetszést ejtünk a mutatóujj alappercének bázisán ulnarisan, $s$ átvágjuk az EIP tapadását olyan distalisan, amennyire csak lehet.

- 2-3 cm-es haránt bőrmetszést ejtünk a kézháton, felkeressük a distalisan már átvágott EIP inat, s előhúzzuk a sebből az ínvéget, majd az inat hosszában megfelezzük.

- Oldalsó középmetszésből feltárjuk az extensor 
apparátus radialis oldalsó kötegét a gyưrús és a kisujj alappercén, majd

- a hosszában felezett ín egyik szárát a III-IV, a másik szárát a IV-V intermetacarpalis térben, a feszítőinak mellett kivezetjük az alappercek radialis oldalához, s tensio mellett, erős varratokkal (4/0) az egyiket a gyürüs ujj, a másikat a kisujj radialis oldali extensor aponeurosis széli részéhez rögzítjük (3. ábra)

A mútét lényegében tenodesisnek tekinthető, mert az alapperc nyújtott, illetve túlnyújtott helyzetét megszünteti, s egyidejűleg a musculi extensor digitorum communist (EDC) feszíti, ezzel lehetővé teszi a két distalis phalanx extenzióját.

\section{B) BRAND módszere szerint}

Cél: mindkét interphalangealis ízület aktív nyújtása

Indikáció: rövid extensorok pótlása

Mútét képlete:

$\mathrm{ECRB}+$ graftok $\rightarrow$ ad tractus lateralis II-III-IV-V

\section{Mütéti technika:}

- Harántmetszés az ECRB tapadása fölött, a csuklón. A bőrmetszéstól 2 harántujjal proximalisabban átvágjuk az ECRB tapadását, s e metszésen át kihúzzuk az ín végét, amelybe így könnyebb lesz a hosszabbító índarabot befonni. Több kisebb bőrmetszésből eltávolítjuk az egyik alsó végtagról a musculus plantaris inas részét olyan hosszméretben, hogy 2-2 ujjra elegendő legyen a kézen.

- Az íntranszplantátumot - plantaris ín - hosszában félbevágjuk, s az ECRB végén, külön-külön kicsiny nyílásokon áthúzzuk a két índarabot a hosszuk feléig, és varratokkal rögzítjük.

- A graftok végeit behúzzuk a kézháton az intermetacarpalis terekbe, s a hosszú ujjak alapperceinek mediolateralis oldalán készített kicsiny feltárásokon át, eszközzel kihúzzuk (a mutatóujjon ulnarisan, a középső, gyűrűs- és kisujjon radialisan), s párhuzamosan az interosseusok inas részével, tensio mellett az extensor aponeurosishoz varrjuk és kihúzható drótvarratokkal a csontokhoz rögzítjük (4. ábra).

Mindkét mútéti típusnál a sebzárás után 3 heti gipszrögzítés szükséges, melyben a PIP és a DIP ízületeket teljes extenzióban rögzítjük. A Brand-féle mútétnél 4 hét után eltávolítjuk a kihúzható drótvarratokat, s ezt követi a szakszerú utókezelés.

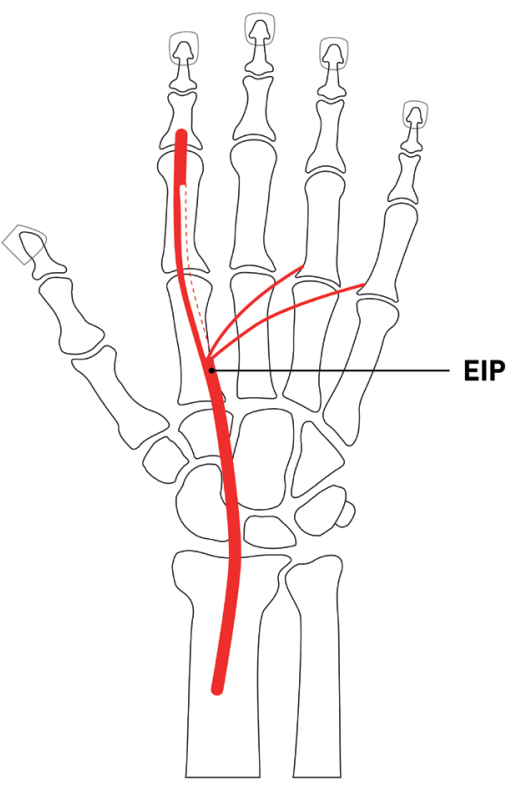

3. ábra Karomtartás megszüntetése feszítő oldali mütéttel: EIP felhasználásával

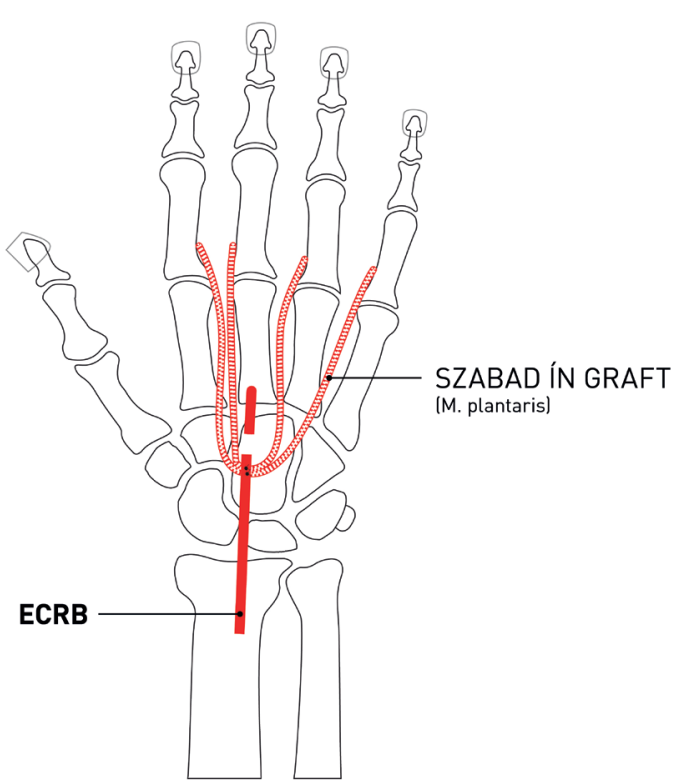

4. ábra Karomtartás megszüntetése feszítő oldali mütéttel: Brand módszere szerint ECRB és szabad ín graft felhasználásával 


\section{Karomtartás megszüntetése hajlító ol- dali mútéttel BUNNELL módszere szerint}

A mútétet eredetileg Nussbaum és Stiles nevéhez kötik (1916), akik attól függően, hány ujjon kívánták az MP ízület hajlítását helyreállítani, egy (FDS III), vagy két (FDS III-IV) felületes hajlítóín áthelyezésével, azok hosszirányú felezésével végezték.

Bunnell (1942) a középső ujj felületes hajlítóinát 3 hosszanti csíkra osztotta, így egyetlen ínnal három ujjon oldotta meg az MP ízület hajlítását (5. ábra).

Cél: az MP ízületek hajlítása

Mütét képlete:

\section{FDS III $\rightarrow \quad$ ad tractus lateralis II-III-IV}

Mütéti technika:

- A középső ujjon, a középpercen leválasztjuk tapadásáról a FDS III.-t, s külön metszéssel feltárva a tenyér proximalis részébent, visszahúzzuk a leválasztott inat,

- három egyenlő vastagságú részre hasítjuk, majd e szárakat a lumbricalis csatornákon keresztül, nagy óvatossággal, kivezetjük a középső, a gyűrús-, és a kisujj alapperc radialis oldalához, ahol az extensor aponeurosis oldalsó szakaszához varrjuk.

- A motorok bevarrása az extensor aponeurosishoz az ízületek következő állásában történjen: csuklóizület $20^{\circ}$-os dorsal extenzióban, MP ízületek $45^{\circ}$-os flexióban, IP ízületek teljesen nyújtva.

- E helyzetben tesszük fel a dorsalis gipszsínt 4 hétre.

- A gipszsín eltávolítása után következik a szakszerű, fokozatos terhelésú aktív ízületi mozgásgyakorlat.

Amennyiben csak a két ulnaris ujjon kívánjuk e módszert alkalmazni, elégséges a IV superficialis inat felhasználni, felezve azt (6. ábra).

\section{Mútét képlete:}

FDS IV $\rightarrow \quad$ ad tractus lateralis IV-V

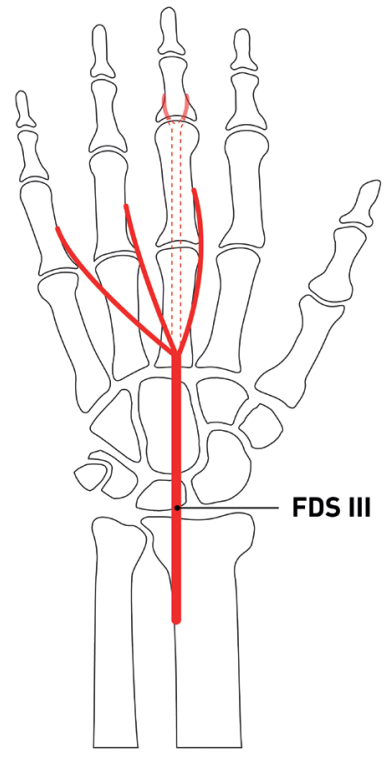

5. ábra Karomtartás megszüntetése hajlító oldali mütéttel: Bunnell módszere szerint FDS III ínnal a középső-, gyürüs-, és kisujjon

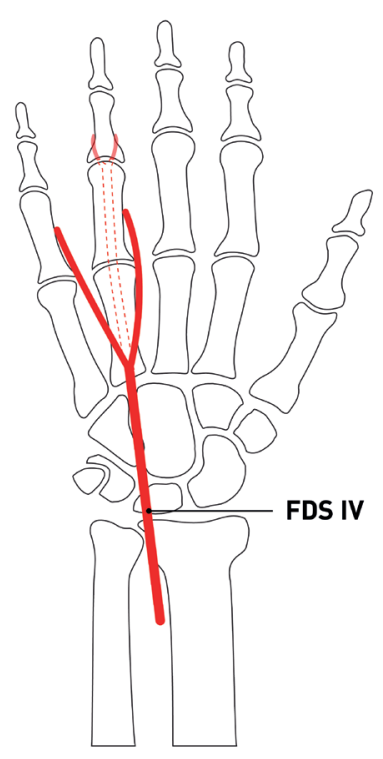

6. ábra Karomtartás megszüntetése hajlító oldali mütéttel: Bunnell módszere szerint FDS IV ínnal csak a gyürüs- és kisujjon 


\section{Karomtartás megszüntetése lasszó plasztikával ZANCOLLI módszere szerint}

Cél: kisfokú karomtartás megszüntetése, ha a betegnek nincs szüksége erős markolásra.

Indikáció: belső izmok kiesése jelentősebb karomállás nélkül, vagy egyszerű karomállás

A módszer lényege: az adott ujj felületes hajlító inát áthelyezzük ugyanazon ujj A2-es ínhüvelygyűrűjére. Leggyakrabban a gyűrűs- és a kisujjon alkalmaztuk.

Előnye: az ín proximal felé helyezésével gyengítjük a középperc flexióját, ami mérsékli a karomtartást.

Hátránya: csökken az ujj fogóereje, összességében gyengül a markoló erő!

\section{Mütéti technika:}

- Ferde metszés az ujj/ujjak palmaris felszínén, az alappercen, amely szükség esetén cik-cakk metszéssel meghosszabbítható a középpercre és a tenyérbe. A metszéseknek az egyes ujjakon párhuzamosan kell futniuk (nem lehetnek egymás tükörképei), hogy a metszések között a bőr keringése ne károsodjon.

- Az A2-es gyűrűtől distalisan megnyitjuk az ínhüvelyt. A felületes hajlító inat 3-4 mm-rel proximalisabban átvágjuk.

- Az MP ízületet 20-30-os, a csuklóízületet $30^{\circ}$ os flexiós helyzetbe állítjuk, s ebben a helyzetben az íngyưrün túlérő végét visszahajtjuk és részben az A2-es gyürühöz, részben a gyürútől proximalisan önmagához levarrjuk (7. ábra).

- Drain fölött zárjuk a feltárást.

Utókezelés: dorsalis gipszsín 4 hétre, majd mozgásgyakorlatok.

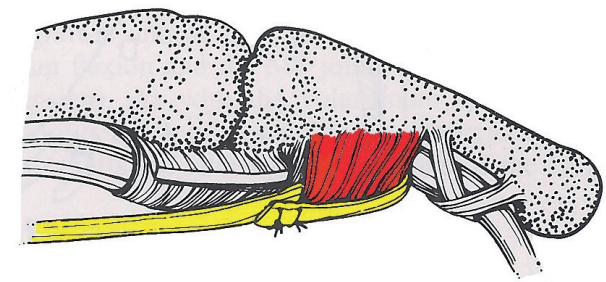

\section{Karomtartás csökkentése} capsulodesissel ZANCOLLI módszere szerint

Cél: MP ízületek hyperextenziós helyzetének megakadályozása.

Indikáció: egyszerű karomtartás, és rendelkezésre álló motor hiánya; komplikált karomtartás, és az MP ízület hyperextenziós contracturája, az IP ízületek fizikoterápiával nem javítható flexiós helyzete.

Egy, vagy több ujjon is végezhető.

Megjegyzés: Saját gyakorlatunkban leggyakrabban ezt a módszert alkalmaztuk.

\section{Mütéti technika:}

- Az operálandó ujjak számától függően haránt bőrmetszést ejtünk a distalis tenyéri barázdában.

- Gondosan eltartjuk az ér, ideg képleteket, az ínhüvelyt szabaddá tesszük, s oldalsó metszéssel megnyitjuk.

- A hajlító inakat, az MP ízületi tok vetületéből kampóval eltartjuk, hogy az inter-metacarpalis ligamentum harántul futó rostjai, $\mathrm{s}$ a palmaris tok egy része látótérbe kerüljön. Vigyázzunk az interphalangealis szalagokra is!

- A palmaris ízületi tokon egy distalisan nyelezett, körülbelül $14 \times 8 \mathrm{~mm}$-es, hosszanti, téglalap alakú lebenyt vágunk ki éles, hegyes szikével, a lebenyt felemeljük és proximal felé húzzuk (8. ábra).

- Behajlítjuk az MP ízületet $20^{\circ}$-os helyzetbe, s a proximal felé húzott lebenyt, 4/0-s fonallal, U-öltésekkel levarrjuk a palmaris ízületi tok maradványához.

- 4-6 hétre dorsalis gipszben rögzítjük az operált ujjat/ujjakat.

- A gipsz eltávolítása után rögzített MP ízületek mellett megkezdjük az IP ízületek mozgatását.

Alternativ lehetőség: a capsulodesis kiegészítéseként az MP ízületet $20^{\circ}$-os hajlított helyzetében egy tűződróttal áttűzzük. Ennek előnye, hogy az IP ízületek ilyenkor, közvetlenül a mútét után azonnal mozgathatók.
7. ábra Karomtartás megszüntetése lasszó plasztikával Zancolli módszere szerint 

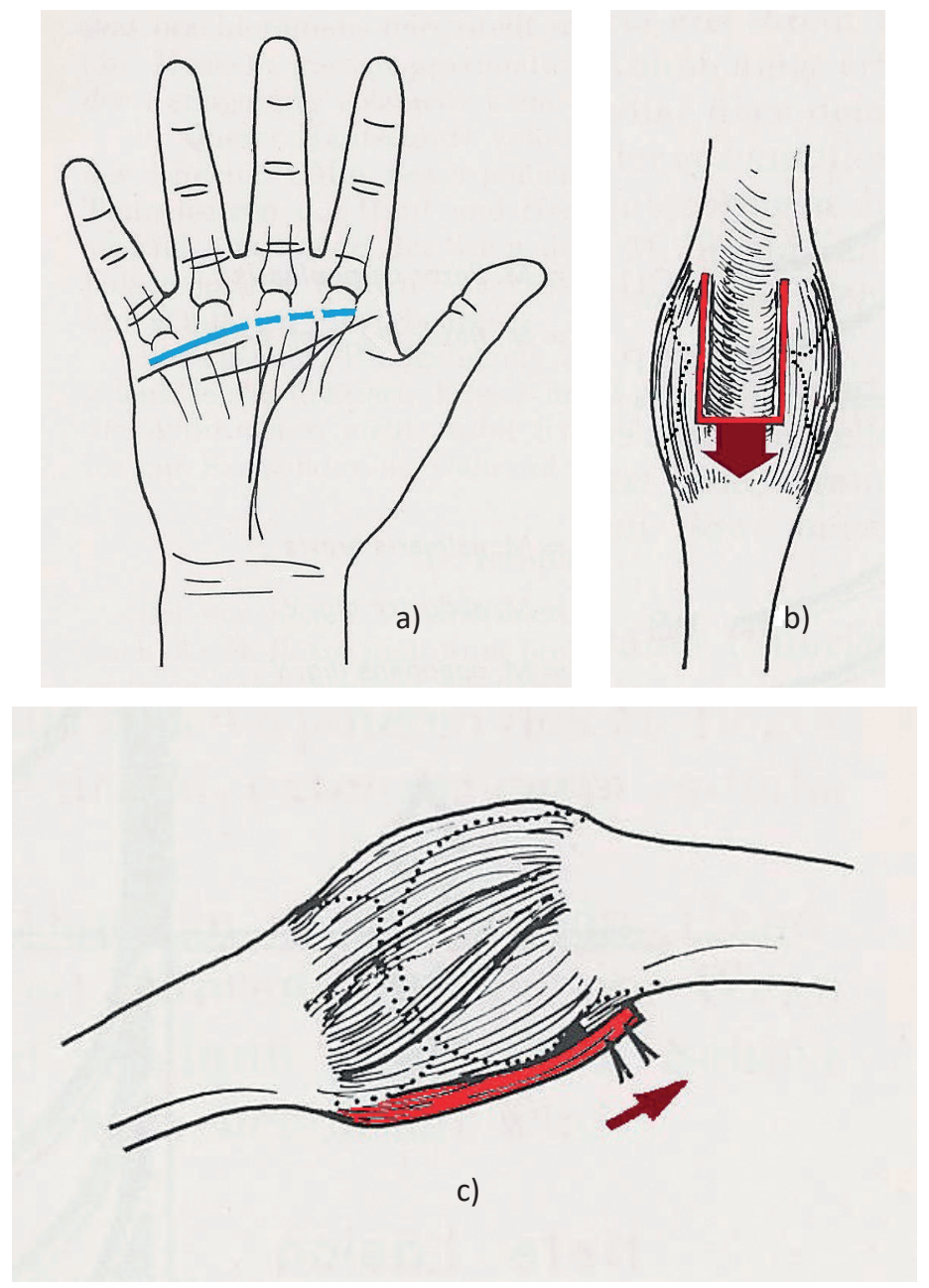

\section{8. ábra}

Karomtartás csökkentése capsulodesissel Zancolli módszere szerint a) tenyéri börmetszés

b) distal felé nyelezett téglalap alakú lebeny képzése

c) az MP ízület $20^{\circ}$-os helyzetében a lebenyt proximal felé húzva U-öltésekkel levarrjuk 


\section{Mutatóujj stabilizálása kulcsfogáshoz}

\section{A) BUNNELL módszere szerint}

Nem növeli a csúcsfogás erejét, viszont jól stabilizálja a mutatóujjat.

Cél: mutatóujj stabilizálása

Indikáció: amikor a betegnek nem erős csúcsfogásra, hanem stabil kulcsfogásra van szüksége

\section{Mútét képlete:}

\section{EIP $\rightarrow$ I. dorsalis interosseusra}

\section{Mütéti technika:}

- dorsalisan haránt, vagy L-alakú metszés a mutatóujj bázisa fölött

- felkeressük az EIP-et, s amennyire csak lehet, distalisan átmetsszük a tapadását

- az inat az EDC II fölött vezetjük és az I dorsalis interosseus ina alatt átbújtatva, a feszítő aponeurosis radialis oldali széléhez varrjuk (9. ábra)

- drain felett zárjuk a feltárást

Utókezelés: dorsalis gipszsín 3 hétre, az MP ízületek $40^{\circ}$-os hajlított helyzetben. Utána fizikoterápia.

\section{B) LITTLER módszere szerint}

A mútéti technika megegyezik a Bunnell módszerénél leírtakkal, de a mutatóujj stabilizálása előtt a hüvelykujj MP ízületében arthrodesist végzünk. Ezzel a két ujj között stabil kulcs- és csúcsfogást hozhatunk létre.

\section{Hüvelykujj adductor pótlása}

Cél: adductio javítása, alapízület stabilitásának helyreállítása

A hüvelykujj adductiójának helyreállításához erős csukló motorra (BR; ECRL; ECRB) van szükség. Mindegyik csuklómotor meghoszszabbítandó szabad íngrafttal. Smith az ECRB-t preferálja, dorsalisan vezetve, Omer szerint is ez a legjobb transzfer. Mi, betegeinknél Solonen-Bakalim leírása után az ECRL-t, és Boyes leírása szerint a BR-t használtuk. Boyes szerint a BR amplitúdója elég a hüvelykujj mozgásához, akár a csukló hajlítását akár a csukló nyújtását végzi a beteg. Ennél a két módszernél az ín bevarrása az ADP tapadásához palmaris alagút felől történik.

\section{A) SOLONEN-BAKALIM módszere szerint} Mütét képlete:

$$
\mathrm{ECRL}+\text { graft } \rightarrow \text { ADP }
$$

Mütéti technika:

- az alkar középső harmadában a radialis oldalon $6 \mathrm{~cm}$-es hosszanti bőrmetszést készítünk a BR és az ECRL közötti vonalban és identifikáljuk az ECRL inat, amelyet amennyire lehet distal és proximal felé mobilizálunk

- ívelt bőrmetszés a kézháton, az ECRL ín tapadása felett, az inat identifikáljuk, majd a tapadásánál átmetsszük és mobilizáljuk, amíg az előző feltárásból már mobilizált szakaszt el nem érjük.

- Több kisebb bőrmetszésből eltávolítjuk az egyik alsó végtagról a musculus plantaris inas részét olyan hosszméretben, hogy az ECRL ínat ezzel meghosszabbítva, a teljes hossz elégséges legyen a palmaris oldali átfordításra, és elérjük vele a hüvelykujjon az ADP tapadásának helyét.

- A szabad íntranszplantátumot (pl. plantaris ín), az ECRL ín szabad végén ejtett nyíláson átbujtatva, U-varratokkal az ínhoz varrjuk.

- A középső tenyéri barázdában indítva ívelt metszés a III-IV metacarpusok proximalis szakasza felett, és rendkívül óvatosan preparálva felkeressük a III-IV intermetacarpalis teret,

- a kézhát bőre alatt alagutat készítünk a IIIIV metacarpus közötti tér felé, s a szabad íntranszplantátummal meghosszabbított inat az intermetacarpalis spatiumon keresztül átvezetjük a palmaris oldalra, $s$ a tenyéri feltáráson keresztül kihúzzuk.

- Az I metacarpuson az abductor pollicis tapadása felett vezetett kis metszésből felkeressük az I. metacarpus tuberculumát, majd innen tompa eszközt vezetünk a tenyéri feltáráshoz úgy, hogy az eszközzel óvatosan, mindig csontközelben haladunk, a palmaris képletek alatt, dorsalisan

- Az eszközbe befogjuk az ínvéget és áthúzzuk az ADP tapadáshoz, ahol az íntapadáshoz és a felette lévő fasciához levarrjuk (10. ábra)

- Az ín bevarrását a csukló $0^{\circ}$-os helyzetében végezzük, eközben a hüvelykujj a mutatóujjhoz képest palmarisan helyezkedjen el.

- Drainek felett zárjuk a feltárásokat. 
Megjegyzés: Fischer (6) utánvizsgálata szerint ezzel a módszerrel a kulcsfogás, a csúcsfogás, és a kéz szorítóereje eléri az ellenoldali kéz teljesítményének a 73\%-át, a hüvelykujj adductio a 63\%-ot, a mutatóujj abductio az 58\%-ot. Véleményét, saját 20 éves tapasztalatunk alapján megerősítjük: mindig elérhető javulás, de soha nem lehet teljes funkciót elérni.

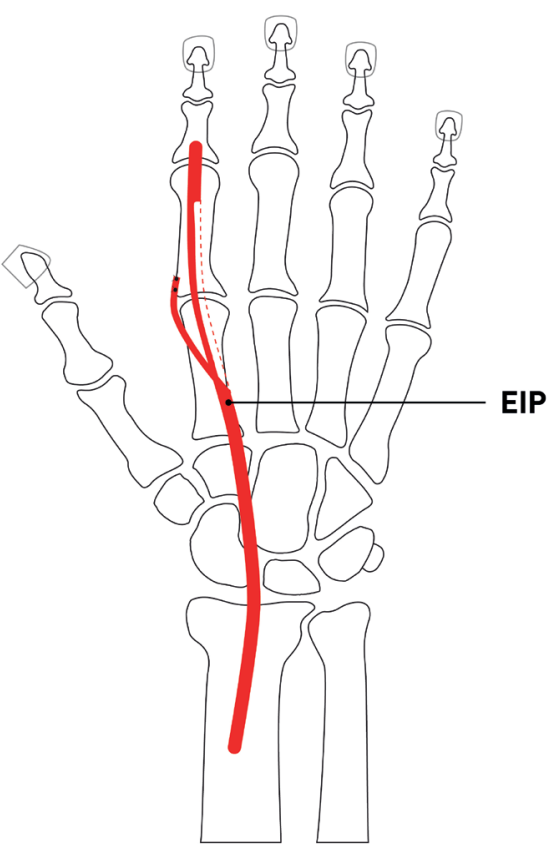

9. ábra Mutatóujj stabilizálása kulcsfogáshoz Bunnell módszere szerint EIP ín felhasználásával

\section{B) BOYES módszere szerint}

Mútét képlete:

$$
\mathrm{BR}+\mathrm{graft} \rightarrow \mathrm{ADP}
$$

\section{Mütéti technika:}

- A feltárás és az áthelyezés menete ugyanaz, mint Solonen-Bakalim módszerénél, csak az ECRL helyett a tőle radialisan elhelyezkedő BR-t váltjuk ki, és hosszabbítjuk meg szabad ín transzplantátummal, majd varrjuk az ADP tapadásához, illetve a fasciához.

Utókezelés: mindkét mútéti típus után dorsalis gipszsín 4 hétre a csukló $0^{\circ}$-os, a hüvelykujj radiopalmaris helyzetében, majd gipszlevétel után szakszerű gyógytorna.

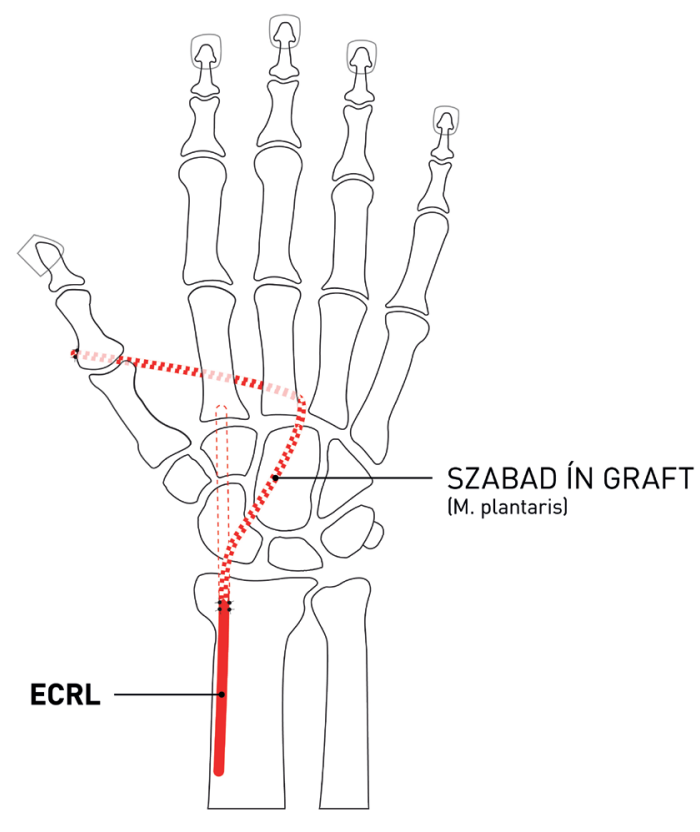

10. ábra Hüvelykujj adductor pótlása Solonen-Bakalim módszere szerint ECRL ín és szabad ín graft felhasználásával

\section{EREDMÉNYEK}

Műtéti szövődményünk, reoperáció, szeptikus szövődmény a kisszámú betegcsoportokban nem volt.

Utókezelés: minden betegünket Intézetünk Rehabilitációs Osztályán kezelték, ahol kiválóan képzett gyógytornász szakemberek optimális mértékben, kitűnő társként vettek részt a végső funkció kialakításában. Az utókezelés ideje alatt rendszeresen konzultáltunk a gyógytornászokkal, mindig megbeszélve a kezelésben esetleg szükséges változtatásokat.

Késői utánvizsgálat: betegeinket átlagosan 3 évig rendszeresen kontrolláltuk, a kontrollvizsgálatok eredményeit minden alkalommal írásban dokumentáltuk (a beteg véleménye, és objektív mérések). A kartonokon rögzített adatokat felhasználtuk az eredmények értékelésekor. 
Az eredmények értékelését a betegek szubjektív véleménye és objektív módszerek alkalmazásával végeztük (10). A DASH kérdőív segítségével mértük fel a betegek szubjektív elégedettségét, az objektív funkciós eredményt pedig a kéz és a kulcsfogás szorítóerejének mérésével határoztuk meg, továbbá mértük a hüvelyk adductiót és a mutatóujj abductiót fokokban, s az adatokat az ellenoldali kézhez viszonyítva százalékban határoztuk meg. A szubjektív és az objektív eredmények összesítése alapján kiváló, jó, megfelelő, és gyenge végső csoportokat tudtunk kialakítani. A proximalis nervus ulnaris sérülés csoportban 3 kiváló, 3 jó, 1 megfelelő és 1 gyenge, míg a distalis nervus ulnaris sérülés csoportban 5 kiváló és 4 jó eredményt kaptunk, itt megfelelő, vagy gyenge nem volt.

\section{MEGBESZÉLÉS}

A nervus ulnaris kiesett funkcióinak pótlására nagyszámú műtéti módszer leírását találjuk az irodalomban $(19,20,24)$. A pótló mútétek utáni eredmények értékelése összehasonlíthatatlanul nehezebb, mint a nervus radialis, vagy a nervus medianus helyreállító mútéteiben, mert az egyes struktúrák funkciójának pótlásakor távolról sem biztos, hogy minden pótolt funkcióban azonosan jó eredményt tudunk elérni $(22,24)$ !

$\mathrm{Az}$ értékelésnél szem előtt kell tartanunk, hogy egy-egy funkció esetleg mérhető jó eredménye, a kéz összfunkciója szempontjából nem biztos, hogy meghatározó, ha a többi funkció pótlása gyengébb.

Magunk is egyetértünk Schink és BuckGramcko véleményével (25), hogy a sebészi kezelés eredményességének végső meghatározásakor, a beteg szubjektív értékelése és az objektív mérések eredményei mellett, elsősorban a fő fogásféleségek elvégzésének a képességét / mértékét, és a korábbi foglalkozás folytatásának fokát is figyelembe kell venni.

A kis esetszám ellenére is kijelenthetjük: a betegek legfontosabb panasza a hosszú ujjak karomtartása, s a kérésük leginkább ennek korrigálására irányult. A kéz deformált helyzete, sok esetben pszichésen jobban zavarja a beteget, mint maga a funkciókiesés (nem domináns kézen például).

A Fowler-, Brand-, Bunnel-féle mútétek eredményességének egymással való összehasonlítása anyagunkban nem lehetséges, a kis esetszám miatt. Kijelenthetjük, hogy mindkét Zancolli-féle mútéti eljárás (lasszó plasztika, és capsulodesis) - a betegek foglalkozása és igénye szerint alkalmazva kiváló eredményt ad.

A mutatóujj stabilizálásra végzett kétféle műtét eredményességének összehasonlítására ugyancsak nincs módunk, gyakorlatunkban az EIP áthelyezését (Bunnell) végeztük, $\mathrm{s}$ az I. MP ízület arthrodesisét kerültük. Mindössze egy fizikai munkás domináns kezén alkalmaztuk.

A hüvelykujj adductio pótlására két betegnél az ECRL inat (Solonen-Bakalim) négy betegnél a BR inat (Boyes) alkalmaztuk. Az eredmények között (Boyes 3/4 jó, 1/4 kiváló; Solonen-Bakalim 2/2 kiváló) szignifikáns eltérést kimutatni nem tudtunk.

\section{KÖVETKEZTETÉS}

Saját eredményeink egyértelműen igazolták, hogy a pótló mútétek még a legsúlyosabb kézfunkció-zavart is eredményesen javítják, elkerülhető a beteg leszázalékolása, $s$ mivel minden esetben figyelembe vettük a beteg munkavégzéséhez szükséges fő funkciók kívánalmait, döntő többségük visszatérhetett eredeti foglalkozásához. A mindennapi életben szükséges tevékenységeket el tudják végezni, önellátásra képesek. A pótló mútétek eredményeit jelentősen javítja, ha a primer, vagy a korai halasztott ellátásban elvégezzük az idegvarratot.

A mútéti eljárások a technikai fejlődéssel együtt folyamatosan finomodnak, ezért fontos az irodalmi közlések naprakész követése, és javasolt az újabb mútéti módszerek kipróbálása, arra alkalmas betegnél. 


\section{IRODALOM}

1. Bíró V.: Funkciópótló eljárások ideghelyreállító mütétek kudarca után a kézen. Irodalmi elemzés. Magyar Traumatológia Ortopédia Kézsebésze Plasztikai Sebészet, 2011. 54. (3): 153-167.

2. Boyes J. H., STARK H. H.: Flexor tendon grafts in the finger and thumb. A study of factors influencing results in 1000 cases. J. Bone Joint Surg. Am. 1971. 53. (7): 1332-1342. https://doi.org/10.2106/00004623-197153070-00008

3. Brand P. W.: Tendon transfers for median and ulnar nerve paralysis. Orthop. Clin. North Am. 1970. 1: 447-454.

4. Brüser P.: Motor replacement operations in chronic ulnar nerve paralysis. Orthopäde, 1997. 26. (8): 690-695.

5. Chung M. S., Baek G. H.: Extensor indicis proprius transfer for the abducted small finger. J. Hand Surg. Am. 2008. 33. (3): 392-397. https://doi.org/10.1016/i.jhsa.2007.12.019

6. Fischer T., Nagy L., Büchler U.: Restoration of pinch grip in ulnar nerve paralysis: Extensor carpi radialis longus to adductor pollicis and abductor pollicis longus to first dorsal interosseus tendon. J. Hand Surg. Br. 2003. 28. (1): $28-32$. https://doi.org/10.1054/JHSB.2002.0858

7. Gohritz A., Fridén J., Herold C., Aust M., Spies M., Vogt P. M.: Ersatzoperationen bei Ausfall motorischer Funktionen an der Hand. Unfallchirurg, 2007. 110. (9): 759-776. https://doi.org/10.1007/s00113-007-1322-7

8. Hastings H., Davidson S.: Tendon transfers for ulnar nerve palsy: Evaluation of results and practical considerations. Hand Clinics, 1988. 4: 167-179.

9. Kovácsy Á., Bíró V.: Ersatz der Intrinsic-Muskelfunktion nach dem modifizierten Zancolli'schen verfahren. Handchirurgie, 1982. 14: 23-28.

10. Mathiowetz V., Kashman N., Volland G., Weber K., Dowe M., Rogers S.: Grip and pinch strength: Normative data for adults. Arch. Phys. Med. Rehabil. 1985. 66. (2): 69-74.

11. Nigst H.: Chirurgie der peripheren Nerven. Thieme Stuttgart, 1955.

12. Nigst H.: Ersatzoperationen nach irreparablen peripheren Nervenläsionen. Schweiz. Arch. Neurol. Neurochir. Psychiatr. 1969. 103. (1): 107-115.

13. Nigst H.: Motorische Ersatzoperationen. In: Wachsmuth W., Wilhelm A. (Eds.) Allgemeine und spezielle chirurgische Operationslehre; Die Operationen an der Hand. Berlin etc. Springer. 1972.

14. Nußbaum A.: Sehnenplastik bei Ulnarislähmung. Zbl. Chir. 1916. 43: 978.

15. Omer G. E. Jr.: Evaluation and reconstruction of the forearm and hand after acute traumatic peripheral nerve injuries. J. Bone Joint Surg. Am. 1968. 50. (7): 1454-1478. https://doi.org/10.2106/00004623-196850070-00016

16. Omer G. E. Jr.: Ulnar nerve palsy. In: Green's Operative Hand Surgery. 4. ed. Vol. 2. Chapter 49. New York etc. Churchill Livingstone. 1999. 1526-1541. p.

17. Ozkan T., Ozer K., Gülgönen A.: Three tendon transfer methods in reconstruction of ulnar nerve palsy. J. Hand Surg. Am. 2003. 28. (1): 35-43. https://doi.org/10.1053/ihsu.2003.50004

18. Rath S.: Immediate postoperative active mobilization versus immobilization following tendon transfer for claw deformity correction in the hand. J. Hand Surg. Am. 2008. 33. (2): 232-240. https://doi.org/10.1016/i.jhsa.2007.10.012

19. Renner A.: Motoros pótlómütétek a kézsebészetben. Elöszó. Magyar Traumatológia Ortopédia Kézsebésze Plasztikai Sebészet, 2012. 55. (4): 287.

20. Renner A., Rupnik J. Jr., Egri L., Szentirmai A.: Motoros pótló mütétek a kézsebészetben I. Általános alapelvek a motoros pótlómütéteknél. Magyar Traumatológia Ortopédia Kézsebésze Plasztikai Sebészet, 2012. 55. (4): 289-292.

21. Renner A., Egri L., Rupnik J. Jr., Zimmermann I., Hardy G., Szentirmai A: Motoros pótló mütétek a kézsebészetben. II. Motoros pótló mütétek - intranszpozíciók a nervus radialis sérülésében. Magyar Traumatológia Ortopédia Kézsebésze Plasztikai Sebészet, 2013. 56. (1): 53-63.

22. Renner A., Egri L., Rupnik J. Jr., Zimmermann I., Hardy G., Szentirmai A: Indications of tendon transfers after non-neural injuries. Abstract Book. XVIIIth FESSH Congress Antalya/Belek Turkey May 29-Jun 1. 2013. 198. p.

23. Renner A., Egri L., Rupnik J. Jr., Zimmermann I., Hardy G., Szentirmai A: Tendon transfers for peripheral nerve injuries on the hand to restore functional motor loss. Abstract Book. XVIIIth FESSH Congress Antalya/Belek Turkey May 29 -Jun 1. 2013. 195. $p$.

24. Sántha E.: Az idegek és az izmok maradandó károsodásai. In: Renner A., Sántha E.: A kéz sebészete. 11. fejezet. Budapest. Kadix Press, 2014. 303-324. p.

25. Schink W.: Motorische Ersatzoperationen nach Nervenverletzungen: Ulnarislähmung. In: Nigst H., Buck-Gramcko D. Millesi H.: Handchirurgie, Band 2. Stuttgart, New York: Thieme, 1983. 40.14-40.19 p.

26. Solonen K. A., Bakalim G. E.: Restoration of pinch grip in traumatic ulnar palsy. Hand. 1976. 8. (2): 39-44. https://doi.org/10.1016/0072-968X(76)90058-9

27. Turcsányi I., Fridén J., Renner A., Kertész GY., Mészáros E., Tóth T., Rácz R., Farkas Cs.: Rekonstrukciós mütétek felsó végtagon tetraplegiás betegeknél. A markolás és a kulcsfogás helyreállítása. Magyar Traumatológia Ortopédia Kézsebészet Plasztikai Sebészet, 2007. 50. (1): 50-58.

28. Uchida Y., Sugioka Y.: Electrodiagnosis of Martin-Gruber connection and its clinical importance in peripheral nerve surgery. J. Hand Surg. Am. 1992. 17. (1): 54-59. https://doi.org/10.1016/0363-5023(92)90113-4

29. Zancolli E. A.: Claw-hand caused by paralysis of the intrinsic muscles: a simple surgical procedure for its correction. J. Bone Joint Surg. Am. 1957. 39-A. (5): 1076-1080. https://doi.org/10.2106/00004623-195739050-00007 
30. Zancolli E. A.: Correction de la garra digital por parálisis intrinseca. La operación del lazo. Acta Ortop. [Latino Americana]. 1974. 1: 65-72.

31. Zancolli E. A.: Intrinsic paralysis of the ulnar nerve - physiopathology of the claw hand. In: Zancolli E. A. (Ed.): Structural and dynamic bases of hand surgery. 2. ed. Philadelphia, Toronto: Lippincott, 1979. 159-206. p.

32. Zrubeczky G.: Die operative Wiederherstellung des Spitzgriffes bei einer irreversiblen Ulnarislähmung. Arch. Orthop. Unfallchir. 1960. 51: 582-591. https://doi.org/10.1007/BF00415024

\section{Prof. Dr. Renner Antal}

Péterfy Kórház-Rendelőintézet Országos Traumatológiai Intézet

1081 Budapest

Fiumei út 17. 
